\title{
Pracownie badań nad lokalnymi problemami społecznymi
}

\section{Streszczenie}

W artykule ukazano koncepcję planowania strategicznego zaadaptowaną do realiów pomocy społecznej i starano się dowieść, że koncepcja ta znacząco wpływa na rozwój badań nad lokalnymi problemami społecznymi, jakie prowadzi się w jednostkach organizacyjnych pomocy społecznej. Ta coraz bardziej znacząca aktywność, dotycząca głównie diagnozowania i prognozowania, wpływa zarówno na wyodrębnianie się nowych zadań pomocy społecznej, a w konsekwencji nowych elementów jej struktur organizacyjnych, które nazwano w tytule artykułu lokalnymi pracowniami badań nad polityką społeczną, jak i na potrzebę przekazywania tych zadań specjalistom polityki społecznej.

Słowa kluczowe: diagnozowanie społeczne, problemy społeczne, polityka społeczna, zarządzanie strategiczne

Kody klasyfikacji JEL: H70, H75, H79

1 Uniwersytet Pedagogiczny im. Komisji Edukacji Narodowej w Krakowie, Instytut Spraw Społecznych, Katedra Gerontologii Społecznej i Pedagogiki Pracy, e-mail: beata.ziebinska@up.krakow.pl, https:// orcid.org/0000-0003-38414885 


\title{
Research laboratories for local social problems
}

\begin{abstract}
The article presents the concept of strategic planning adapted to the realities of social assistance and attempts to prove that this concept significantly affects the demand for research on local social problems that is carried out in local social assistance institutions. This increasingly significant activity, mainly concerning diagnosing and forecasting, influences both the identification of new tasks of social welfare and, consequently, new elements of its organizational structures, which were called local laboratories for research on social policy in the title of the article, and the need to delegate these tasks to specialists in social policy.
\end{abstract}

Keywords: social diagnosis, social problems, social policy, strategic management JEL Classification Codes: H70, H75, H79

Celem artykułu jest ukazanie wpływu koncepcji zarządzania strategicznego i planowania społecznego na wzrost znaczenia badań nad lokalnymi problemami społecznymi, a także przedstawienie, jak podejście związane z planowaniem strategicznym wpływa na wyodrębnianie się nowych zadań pomocy społecznej, a w konsekwencji nowych elementów jej struktur organizacyjnych - nazwano je w tytule artykułu lokalnymi pracowniami badań nad polityką społeczną. Ważność badanej problematyki wynika po pierwsze $\mathrm{z}$ faktu, że istnieje niezagospodarowana przestrzeń do poszukiwań badawczych odnoszących się do rosnącego znaczenia badań zmierzających do diagnozowania lokalnych problemów społecznych oraz ewaluacji lokalnej polityki społecznej, a po drugie ze wzrastającego znaczenia zawodu specjalisty polityki społecznej jako tego, którego kompetencje wydają się właściwymi do realizacji zadań, jakie stawia przed samorządami konieczność tworzenia i realizacji długookresowych strategii rozwiązywania problemów społecznych oraz programów społecznych.

Dotychczasowe publikacje związane z poruszaną tu tematyką skupiają się na analizie podstawowych założeń zarządzania publicznego (Supernat, 2004; Kożuch, 2004; Sześciło, Medins, Niziołek, Jakubek-Lalik, 2014; Raczkowski, 2015; Kożuch, 2016), prezentacji znaczenia i sposobu tworzenia dokumentów strategicznych w samorządach (Grewiński, Karwacki, 2009; Krzyszkowski, Przywojska, 2009; Głąbicka, 2013; Klimek, 2020), diagnozowaniu w polityce społecznej (Czekaj, 2007; Szatur-Jaworska, 2013), problemach ewaluacji w polityce społecznej (Olejniczak, 2008; Theiss, 2010; Surdej, Fitz-Gibbon, Picciotto, 2013; Podkońska, 2016), roli obserwatoriów terytorialnych i żywych laboratoriów w zarządzaniu polityką rozwoju miast (Grochowski, 
2011; Woźniak, 2012; Klimowicz, 2015; Brodowicz, Stelmach-Fita, 2017; Baran, 2020) czy wpływie paradygmatów aktywizacji i wielosektorowości na realizację polityki społecznej (Grewiński, Lizut, 2013), natomiast brakuje analiz odnoszących się do zagadnień łączących te wątki i dowodzących wzrostu znaczenia badań społecznych w lokalnej polityce samorządowej, a także wpływu tego zjawiska na przeobrażenia struktur organizacyjnych pomocy społecznej. Stosunkowo niewiele uwagi poświęca się też analizie zawodu specjalisty polityki społecznej. W artykule udzielono odpowiedzi na następujące pytania badawcze: Czym jest diagnozowanie problemów społecznych w lokalnej polityce społecznej? Jakie są najważniejsze założenia w koncepcji zarządzania strategicznego oraz planowania społecznego i jak wpływają one na konieczność prowadzenia lokalnych badań społecznych? Jakie elementy struktury organizacyjnej jednostek pomocy społecznej realizują zadania badawczo-analityczne? Jakie umiejętności specjalistów polityki społecznej mogą być wykorzystane podczas realizacji zadań badawczych w pomocy społecznej?

Badanie przeprowadzono zarówno na podstawie analizy literatury przedmiotu, jak i analizy instytucjonalno-prawnej polegającej na opisie działania instytucji oraz mechanizmów jej funkcjonowania. Badaniu poddano dokumenty prawne, takie jak powszechnie obowiązujące akty prawne (Ustawa o pomocy społecznej oraz Ustawa o realizacji usług społecznych przez centrum usług społecznych), a także dokumenty opracowywane przez ośrodki pomocy społecznej - ich statuty i regulaminy organizacyjne, które wybrano w sposób celowy - według kryterium wyodrębnienia w schemacie organizacyjnym komórki ds. strategii. Przeanalizowano dokumenty 10 ośrodków funkcjonujących w miastach wojewódzkich (m.in. w Warszawie, Krakowie, Gdańsku, Opolu, Wrocławiu, Lublinie, Katowicach). Analizowano zarówno umiejscowienie tych komórek w ogólnej strukturze ośrodków, jak i realizowane w nich zadania. W przypadkach kiedy zadania związane z planowaniem strategicznym w dziedzinie społecznej realizowane są w urzędach miejskich, analizowano także regulaminy organizacyjne tych urzędów.

Zasadnicza teza artykułu została sformułowana następująco: Wraz z coraz bardziej zaawansowanym rozwojem zarządzania publicznego w realiach pomocy społecznej wzrasta potrzeba realizacji badań nad problemami i kwestiami społecznymi w lokalnej polityce społecznej, co implikuje zarówno zmiany struktur (schematów) organizacyjnych pomocy społecznej, jak i zaangażowanie w proces planowania strategicznego specjalistów, posługujących się instrumentarium potrzebnym do realizacji rozmaitych badań, służących zwłaszcza diagnozowaniu oraz ewaluacji. 


\section{Diagnozowanie problemów społecznych w lokalnej polityce społecznej}

Termin problem, o greckiej proweniencji, oznacza pewną trudność, zadanie wymagające rozwiązania, rozstrzygnięcia (Tokarski, 1980: 601). Choć w naukach społecznych napotykamy wiele jego znaczeń, to w kontekście polityki społecznej i podjętego tematu istotne jest głównie wąskie rozumienie tego pojęcia, w którym są to problemy określane jako tylko te zjawiska i zdarzenia, które Sztumski (2020: 57) nazywa niepożądanymi, kłopotliwymi, wywołującymi określony rezonans w świadomości ludzi danego społeczeństwa lub społeczności. Z czego wynika, że mianem tym będziemy określali problemy powodujące sytuacje, które nie dają się pogodzić z powszechnie uznanymi w danym społeczeństwie normami, wartościami i co do których istnieje przekonanie, że mogą być rozwiązane lub przezwyciężone poprzez aktywność społeczną. Podobne znaczenie ma określenie „kwestia społeczna”. Danecki zauważa, że skupienie uwagi na kwestiach społecznych oraz sposobach ich ograniczania i rozwiązywania jest właśnie wyróżnikiem perspektywy poznawczej polityki społecznej: „Jest to $\mathrm{w}$ istocie sam rdzeń nauki o polityce społecznej rozumianej szeroko jako działalność na rzecz usuwania przeszkód blokujących poprawę jakości życia w jej rozmaitych przejawach i skalach współżycia społecznego" (Danecki, 1998: 23).

Rozpoznawanie kwestii społecznych i wąsko rozumianych problemów społecznych jest przedmiotem diagnozowania w polityce społecznej - pojęcia rozumianego przynajmniej dwojako. Po pierwsze za diagnozowanie możemy uznawać wszelkie społeczne badanie empiryczne, w którym zbiera się i porządkuje dane, a następnie je interpretuje, by odpowiedzieć na pytania o to, jak przedstawia się problem i dlaczego tak jest. Przedmiotem badania w polityce społecznej są więc, w tym przypadku, różnego rodzaju zjawiska i procesy społeczne, a efektem twierdzenia o charakterze praktycznym (Szatur-Jaworska, 2013: 110). Po drugie diagnozowaniem określimy też rozpoznawanie zdarzeń i sytuacji społecznych ze względu na ich dotkliwość i potrzebę zmian (Kubin,1998: 134; Szatur-Jaworska, 2013: 110). Drugie ujęcie wydaje się odpowiadać bardziej diagnozowaniu w pomocy społecznej, podczas gdy pierwsze jest szersze i dotyczy różnych tematów z obrębu polityki społecznej, jednak w efekcie obu typów diagnozowania możemy wysnuć wnioski i zalecenia dla praktyki społecznej.

W polityce społecznej, także w tej lokalnej (gminnej, powiatowej), obok badań diagnostycznych możemy wyróżnić również inne rodzaje badań, skoncentrowanych na odmiennej problematyce. Szatur-Jaworska (2013: 110) przedstawia taką klasyfikację: (1) ewaluacyjne, mające na celu ocenę realizowanej polityki społecznej, (2) 
prognostyczne, określające przewidywane na podstawie analizy wskaźników zaobserwowane trendy i ich związek z efektami działań oraz (3) porównawcze, wskazujące na podobieństwa i różnice między wspólnotami lokalnymi. Badania te mają charakter interdyscyplinarny, co przejawia się zarówno podczas samego prowadzenia badań, jak i ich interpretacji, kiedy odwołujemy się do różnych dyscyplin (politologii, socjologii, psychologii). Sprzyja to wypracowaniu różnych podejść badawczych oraz szerokiej interpretacji badanych procesów i zjawisk, syntezie wyników badania czy wreszcie adaptacji teorii pochodzących z pokrewnych dziedzin.

Diagnozowanie, monitorowanie czy szerzej ujmując, stosowanie wyników badań naukowych w celu rozwiązywania problemów społecznych, przywodzi na myśl koncepcję polityki społecznej opartej na dowodach (evidence-based policy), której główną cechą ma być jej nieideologiczny charakter, zapewniony przez naukową rzetelność i metodologiczną poprawność wykorzystywanych w polityce badań. Polityka tego typu jest przeciwstawną do tej opartej na przekonaniach (convictio-based policy), używającej dowodów w sposób selektywny lub wykorzystującej poglądy jednostek odwołujące się głównie do ideologii i przesądów (Górniak, Mazur, 2011: 13; Klingemann, 2013). Jest tą, która umożliwia „sumienne i jawne” wykorzystanie w procesach decyzyjnych i przy wyborach strategii politycznych najlepszych dostępnych danych empirycznych. Istotą tego procesu ma być oparcie decyzji i działań na wiedzy, która jest tworzona na podstawie procedur badawczych wykorzystywanych w nauce. Badacze wyróżnili kilka poziomów możliwego zastosowania wiedzy naukowej. Pierwszy z nich określony jako celowy (socjotechniczny) polega na bezpośrednim wpływie wiedzy na politykę społeczną, drugi - koncepcyjny (edukacyjny), w którym wiedza wpływa na zmianę świadomości poprzez umożliwienie głębszego zrozumienia pewnych zagadnień oraz poziom trzeci - symboliczny, kiedy wiedza wykorzystywana jest wyłącznie do legitymizacji obecnie realizowanej lub zamierzonej polityki społecznej (Frieske, 1990, 2008; Mitton et al., 2007; Klingemann, 2013). Badania nad procesami wykorzystania dowodów pochodzących ze świata nauki w rozmaitych dziedzinach życia zbiorowego sięgają lat 70. XX w., a popularność tego rodzaju polityki obserwujemy szczególnie podczas tzw. nowego zarządzania publicznego w krajach anglosaskich. Obecnie polityka oparta na dowodach jest postępowaniem rekomendowanym rządom państw Unii Europejskiej, a poza tym ten racjonalno-pozytywistyczny sposób zarządzania sprawami publicznymi promują też inne międzynarodowe podmioty polityki, np. Bank Światowy czy OECD. 


\section{Badania lokalnych problemów społecznych w kontekście planowania społecznego i zarządzania strategicznego}

Wraz z ucieleśnieniem nowych paradygmatów w polityce społecznej (m.in. aktywizacji, deinstytucjonalizacji, wielosektorowości czy innowacyjności) następuje stosunkowo szybki rozwój badań nad problemami społecznymi w jednostkach pomocy społecznej, głównie w ośrodkach pomocy społecznej i powiatowych centrach pomocy rodzinie. To zjawisko wydaje się mieć związek także z realizowanymi w polityce społecznej przynajmniej dwiema koncepcjami. Jest to zarówno odrodzenie idei planowania społecznego, związanego z planowaniem miast, jak i coraz większe znaczenie tzw. nowego zarządzania publicznego, które w myśleniu o administracji publicznej odzwierciedla główne postulaty neoliberalnej szkoły ekonomicznej.

Koncepcja, której adaptacja do lokalnej polityki społecznej wpływa coraz bardziej znacząco na rozwój skali badań nad problemami społecznymi - planowanie społeczne - ma związek z planowaniem fizycznej zmiany infrastruktury miast, rozwijającej się dzisiaj głównie za sprawą programów rewitalizacji gmin. Planowanie społeczne jest jednak ideą powstałą stosukowo dawno. W publikacjach poświęconych historycznemu ujęciu tego zagadnienia (Czekaj, 2007; 2015) zauważa się, że planowanie było funkcją władzy lokalnej w pierwszej dekadzie XX w., kiedy to powstały pierwsze komisje planowania rozwoju miast, np. Chicago czy Nowego Jorku. Natomiast w Europie rozwój planowania następował po drugiej wojnie światowej, przede wszystkim w Wielkiej Brytanii, Francji, Szwecji, Holandii, Finlandii. Z kolei w państwach realnego socjalizmu planowanie było nie tylko domeną architektów i polityków, ale uwzględniało też planowanie społeczne. Ziółkowski określił je jako: „całokształt działań mających na celu sformułowanie polityki i programów dotyczących sektorów społecznych gospodarki (takich jak szkolnictwo, zdrowie, ubezpieczenia społeczne, praca wspólnot terytorialnych), jak również społecznych aspektów sektorów materialnych i ekonomicznych (przemysł, mieszkania, transport publiczny)" (Ziółkowski, 1972: 3). Wraz ze zmianą społeczną w 1989 r. zaniechano planowania społecznego, a następnie powrócono do realizacji tej idei po wstąpieniu do Unii Europejskiej, kiedy nowe wyzwania i założenia polityki społecznej wpłynęły na potrzebę rozwoju wiedzy o zjawiskach i problemach społecznych w polskich gminach, powiatach i regionach. Warto dodać, że tematyka planowania życia w miastach wiąże się, od kilku już dziesięcioleci, także z koncepcją poprawy jego jakości zarówno w odniesieniu do jego przestrzeni fizycznej i intelektualnej, jak i ludzi - jednostek i grup społecznych, wspólnie tworzących miejskość i doświadczających owej miejskości. Jakość życia w mieście może być rozumiana rozmaicie. Najogólniej ujmując, można 
ją określić jako zaspokojenie wymagań i potrzeb określających poziom duchowego i materialnego bytu zarówno poszczególnych jednostek, jak i całego społeczeństwa. Badając jakość życia miejskiego, analizuje się zazwyczaj pewne wskaźniki ilościowe i jakościowe, zarówno obiektywne, takie jak np. przeciętne trwanie życia czy poziom zanieczyszczenia środowiska, jak i subiektywne - stopień zadowolenia z warunków życiowych, poczucie zaspokojenia wybranych potrzeb i aspiracji czy dobrostan psychiczny i stres życiowy. Z ideą tą łączy się też koncepcja zrównoważonego rozwoju, u podstaw której leży przekonanie o konieczności takiego modelowania gospodarki, które umożliwia świadome kształtowanie relacji między wzrostem gospodarczym, dbałością o środowisko oraz jakością życia człowieka (Piasny, 1993; Petelewicz, Drabowicz, 2016; Wyszomirski, 2017).

Idea planowania miast i poprawy jakości życia w mieście wiąże się obecnie nierozłącznie z koncepcją tworzenia i monitorowania polityki rozwoju, co z kolei przywodzi na myśl instytucje, których zadaniem jest prowadzenie badań i analiz strategicznych dotyczących problemów społeczno-gospodarczych, jak Krajowe i Regionalne Obserwatoria Terytorialne czy tzw. żywe laboratoria polityk publicznych będące odpowiedzią na jeden $\mathrm{z}$ dominujących w polityce publicznej paradygmatów - innowacyjności (Grochowski, 2011; Klimowicz, 2015; Brodowicz, Stelmach-Fita, 2017). Obserwatoria terytorialne polityk publicznych (np. polityki społecznej, polityki rozwoju czy rynku pracy i edukacji), działające od około dekady, powstały w konsekwencji realizacji jednego z zamierzeń Krajowej Strategii Rozwoju Regionalnego. Do ich zadań należy ocena dostępu do informacji i systematyczne diagnozowanie społecznych problemów regionów, badanie trendów rozwojowych w obszarze społecznym - dla potrzeby planowania strategicznego, co z kolei łączy się z systemem monitorowania różnych procesów rozwojowych w regionach (Grochowski, 2011; Brodowicz, Stelmach-Fita, 2017). W założeniu proces ten zmierza do oceny realizacji polityki spójności i związanych z tym wydatków. Rozwój diagnozowania problemów społecznych splata się także, jak wspomniano, z coraz popularniejszą ideą żywych laboratoriów, czyli miejsc organizowania i zarządzania innowacjami. Powodzenie tej koncepcji w Europie wynika z upowszechniania nowych rozwiązań poprzez unijny program ramowy w zakresie badań naukowych i innowacji, a od 2004 r. jest pokłosiem współpracy międzynarodowej grupy eksperckiej działającej z Komisją Europejską oraz (od 2006 r.) Europejskiej Sieci Żywych Laboratoriów. Poprzez tego typu laboratoria świat nauki współpracuje z sektorem publicznym, prywatnym i społecznym (tzw. poczwórna helisa) w celu tworzenia innowacyjnych rozwiązań dotyczących życia społecznego i gospodarczego. Sektor publiczny w tej koncepcji odpowiada za rozpoznawanie i diagnozowanie problemów społecznych, tworzenie nowych rozwiązań tych problemów oraz umożliwienie społeczeństwu uczestnictwa w procesach (Leminen, 2013). 
Kolejnym istotnym podejściem wpływającym na rozwój badań nad problemami społecznymi, zespolonym z przedstawionymi podejściami, jest paradygmat zarządzania publicznego. Pojęcie to jedna $\mathrm{z}$ definicji przedstawia jako „ogół działań różnego typu podmiotów na rzecz zaspokajania potrzeb zbiorowych, którego aktorami są zarówno instytucje publiczne (państwo, samorządy, UE), jak i prywatne - przedsiębiorcy, organizacje pozarządowe, a nawet indywidualni obywatele" (Sześciło, Medins, Niziołek, Jakubek-Lalik, 2014: 20). Zarządzanie publiczne jest próbą adaptacji do realiów, w jakich działają organizacje publiczne klasycznych koncepcji organizacji i zarządzania, opartych na specyficznych działaniach instytucji rynkowych, które mają na celu zwiększenie wydajności i w konsekwencji zysku. Często oznacza to, że w administracji stosuje się metody i techniki zarządzania wykorzystywane w biznesie, do których należy m.in. zarządzanie strategiczne.

Zarządzanie strategiczne oparte jest na strategii i rozumiane w organizacjach w różny sposób, w zależności od przyjętych założeń. Tę odmienność odzwierciedlają główne podejścia do tego zarządzania, m.in. planistyczne, ewolucyjne (inkrementalne), pozycyjne oraz zasobowe (Obłój, 1998: 54-55; Miżejewska, 2016). Wydaje się, że pierwsza z wymienionych perspektyw - planistyczna wywarła znaczący wpływ na potrzebę diagnozowania, najpierw w sektorze komercyjnym, a następnie w politykach publicznych, w których zaadaptowano ją do realiów innych niż rynkowe.

$\mathrm{W}$ perspektywie planistycznej zmierza się do badania tego, co dzieje się w organizacji i jej otoczeniu. Za jej początek w zarządzaniu przyjmuje się lata 50. XX w., kiedy w 1954 r. Drucker opisał podejście oparte na dyscyplinie planowania i realizowania celów, które nazwał zarządzaniem przez cele (Management by Objectives - MBO). Według niego zarządzanie polega na równoważeniu niejednorodnych potrzeb i celów, a strategia jest zintegrowanym planem działan prowadzących do realizacji długookresowych celów oraz rozdziału zasobów. Szkoła planistyczna proponowała sformalizowany proces tworzenia strategii, oparty na bogatej analizie przypisanej wybranym do tworzenia planów komórkom organizacyjnym (Ansoff, 1985; Mintzberg, 1994; Obłój, 1998).

Mimo że w późnych latach 70 . XX w. nastąpił schyłek podejścia planistycznego w klasycznym ujęciu, to na początku lat 90 . zaobserwowano renesans tej koncepcji za sprawą twórców założeń Zrównoważonej Karty Wyników (Balanced Scorecard - BSC). Kaplan i Norton sformalizowali proces planowania strategicznego poprzez wprowadzenie pomiaru wskaźników istotnych dla strategii, kontrolę na etapie wdrożenia oraz promowanie jej założeń. Autorzy postulowali zdyscyplinowany proces planowania strategii i kontroli poprzez wyrażone liczbowo cele i systematyczne monitorowanie ich osiągania (Miżejewska, 2016). 
Z punktu widzenia znaczenia i adaptacji szkoły planistycznej do zarządzania publicznego warto zwrócić uwagę na kilka jej przesłanek, przyjmowanych obecnie w sektorze publicznym i przyczyniających się do rozwoju potrzeby prowadzenia badań społecznych. Po pierwsze zakłada się w tej szkole przewidywalność otoczenia i możliwość dogłębnej analizy samej organizacji. Do badania tych zjawisk służy m.in. popularny od lat 60. XX w. model analizy SWOT (akronim od angielskich słów: strengths - przewagi, weaknesses - słabości, opportunities - szanse i threats - zagrożenia). W szkole planistycznej korzysta się także z narzędzi do analiz studiów przypadku (case studies), a także narzędzi analitycznych ułatwiających badanie makrootoczenia organizacji, np. PEST - analiza zestawiająca podstawowe czynniki zewnętrzne organizacji (political - polityczne, economic - ekonomiczne, social - społeczno-kulturowe i technological - technologiczne). Analiza otoczenia w założeniu wzbogaca w wiedzę, na podstawie której można wytyczać granice zmian (Ansoff, 1985: 104). Racjonalność podejmowania decyzji jest kolejnym założeniem szkoły planistycznej, które doprowadziło do stworzenia instrumentarium wspomagającego osoby zarządzające - szczegółowo opisane techniki analiz, diagramy i wzory stanowiły kanon planowania strategicznego. W perspektywie planistycznej strategia jest długookresowym planem, zazwyczaj pięcioletnim, w podejściu planistycznym istnieje podział na twórców strategii (zazwyczaj naczelne kierownictwo firmy) i jej wykonawców.

Sam proces planowania strategii może być przedstawiony jako schemat złożony z diagramów, pokazujący etapy prac rozpisane na zadania oraz osoby odpowiedzialne za ich realizację. W jego wyniku formułuje się cele, a następnie - bazując zazwyczaj na wynikach analizy SWOT - przygotowuje sekwencję działań z wykorzystaniem wykresów, tabel i list kontrolnych. Plan strategiczny kończy się budżetem oraz planami operacyjnymi, a cały proces jest przedstawiony na złożonym diagramie pokazującym sekwencję działań (Miżejewska, 2016). Typowy model planowania strategicznego zaproponowany przez uczonego ze Związku Radzieckiego Ansoffa stosowany zarówno w firmach, jak i organizacjach niedochodowych składa się z ośmiu elementów: misja, cele, analiza otoczenia zewnętrznego, analiza otoczenia wewnętrznego, opracowanie alternatyw strategicznych, wybór strategii, jej wdrożenie, a następnie kontrola (Ansoff, 1985).

Mimo że nawet sam Ansoff dostrzegał ryzyko zapętlenia w procesie analizy, bo często potrzeby informacyjne planistów rosną wraz z pojawieniem się kolejnej informacji, a jego adwersarz Mintzberg dowodził, że „nie wszystkie zmiany są cykliczne i wynikają z przeszłości (...). Analiza, na której opiera się planowanie strategiczne, nie radzi sobie $\mathrm{z}$ radykalnymi zmianami w otoczeniu (...) powinna być wsparciem dla tego procesu, ale nie może go zastąpić” (Mintzberg, 1991: 92), to trudno dzisiaj wyobrazić sobie tworzenie strategii w globalnych przedsiębiorstwach, które nie byłoby 
zaplanowanym z wyprzedzeniem procesem, skoordynowanym w czasie i przeprowadzonym w zbliżony sposób we wszystkich krajach. Proces planowania wpływa na myślenie o przyszłości i zachęca do refleksji nad obranym kierunkiem rozwoju. Uważa się też, że trudności w przewidywaniu przyszłych zdarzeń nie zwalniają z konieczności podejmowania takich prób. Z tego powodu pomocne są metody prognozowania zarówno ilościowe (np. pokazanie trendu), jak i jakościowe (np. metody scenariuszowe) oraz tworzenie działów planowania i analiz, które dysponują coraz lepszym wsparciem informatycznym ułatwiającym prowadzenie diagnoz, analiz i prognoz.

Jak wspomniano, metody i techniki zarządzania wypracowane na gruncie instytucji komercyjnych adaptowane są stale do potrzeb instytucji publicznych, również do sektora pomocy społecznej (Grewiński, Lizut, 2016; Klimek, 2020; Krzyszkowski, Przywojska, 2009). Jednym z najczęściej stosowanych narzędzi w tym zakresie stały się strategie rozwoju gmin i powiatów, a także strategie rozwiązywania lokalnych problemów społecznych. Pojęciem strategii określa się w tym rozumieniu „dokument, w którym na podstawie rzetelnej diagnozy formułuje się cele priorytetowe i operacyjne, następnie kierunki działania oraz spodziewane i pożądane rezultaty planowanych działań, a ponadto wskaźniki społeczne, które pozwolą ocenić, czy pojawił się oczekiwany rezultat" (Rybka, Trawkowska, 2009: 251). Opracowanie strategii rozwiązywania problemów społecznych jest jednym $\mathrm{z}$ istotnych zadań instytucji pomocowych, określonych w ustawie o pomocy społecznej (Dz.U. 2004 nr 64, poz. 593, art. 16.b.1). Warto zauważyć, że również ustawa o realizowaniu usług społecznych (Dz.U. 2019, poz. 1818, art. 4 i 5) wskazuje planowanie społeczne jako zadanie dla centrów usług, polecając samorządom lokalnym tworzenie programów usług społecznych, których konstruowanie i monitorowanie opiera się na podobnych zasadach jak tworzenie strategii społecznych.

W kontekście opracowywania oraz realizowania strategii rozwoju lub rozwiązywania problemów społecznych możemy wyróżnić dwa etapy: zarządzanie strategiczne i planowanie strategiczne. Zarządzanie strategiczne jest wśród nich pojęciem szerszym, ponieważ obejmuje zarówno proces tworzenia, jak i wdrażania strategii, a istotą jest tu zarówno opracowanie, jak i praktyczne wdrażanie długookresowych programów rozwoju. Natomiast planowanie strategiczne, które z punktu widzenia podjętego tu tematu jest istotniejsze, jest pierwszym, wstępnym etapem zarządzania strategicznego i polega na samym konstruowaniu strategii. Planowanie strategiczne jest przygotowaniem i podejmowaniem decyzji dotyczących podstawowych celów organizacji oraz niezbędnych do ich osiągnięcia zasobów i metod (Klimek, 2020). Jest więc etapem wyznaczania kierunków rozwoju danej organizacji w dłuższej perspektywie czasowej, w tym celów oraz działań ukierunkowanych na ich realizację na podstawie dogłębnej diagnozy i analizy. 
Opracowanie diagnozy problemów społecznych jako elementu planowania strategicznego wymaga od osób zaangażowanych w ten proces specjalistycznego przygotowania, dotyczącego organizowania i prowadzenia badań społecznych. Diagnoza jest nie tylko wstępnym etapem planowania, warunkującym często powodzenie dalszych faz realizacji strategii i programów, ale występuje też w innych momentach działalności prowadzonej przez podmioty lokalnej polityki społecznej - może być przeprowadzona po zakończeniu kolejnych etapów działania (etapowa) oraz po zakończeniu działań.

Część diagnostyczna strategii zawiera charakterystykę aktualnego stanu rozwoju gminy lub powiatu, z uwzględnieniem czynników wewnętrznych oraz zewnętrznych. Diagnoza może ukazywać nie tylko aktualny zakres występowania problemów społecznych w środowisku lokalnym, ale coraz częściej skupia się także na ukazaniu stopnia zaspokojenia potrzeb mieszkańców. Wskazuje także występujące tendencje oraz związki przyczynowo-skutkowe i współzależności rozwojowe. Ważny jej fragment powinna stanowić charakterystyka systemu pomocy społecznej zarówno w wymiarze instytucjonalnym, jak i środowiskowym. Część diagnostyczna strategii powinna umożliwiać ocenę aktualnego stanu samorządu lokalnego w aspekcie zakresu występowania poszczególnych problemów społecznych na jego terenie, a także prognozę rozwojową w określonej perspektywie czasowej. Właściwie przygotowane badanie tego typu powinno mieć, zdaniem Klimka (2020), charakter zarówno ilościowy, jak i jakościowy i dotyczyć demograficznej charakterystyki miejsca, rysu gospodarczego, a także edukacji, ochrony zdrowia, a nawet kultury czy sportu jako obszaru działań profilaktycznych, a następnie odnosić się do dominujących problemów społecznych, takich jak np. ubóstwo, bezdomność, uzależnienia czy problemy osób niepełnosprawnych. Zebrane dane należy w odpowiedni sposób zinterpretować. Trzeba określić występujące tendencje, dlatego warto ukazać skalę zjawiska w ujęciu czasowym (przynajmniej kilku lat) oraz przestrzennym, by z kolei zobrazować skalę problemów społecznych na tle innych, podobnych jednostek samorządu terytorialnego. Diagnozę sporządza się zazwyczaj na podstawie materiałów zastanych, ale można korzystać także z innych metod i technik, jak obserwacja, wywiady czy wreszcie, często stosowane, badania ankietowe prowadzone wśród mieszkańców społeczności lokalnej. Umożliwiają one pokazanie istoty i zakresu występujących problemów społecznych z punktu widzenia mieszkańców (Czekaj, Niesporek, Zawartka-Czekaj, 2009; Klimek, 2020).

Kolejną istotną, ale także wymagającą specjalistycznych umiejętności, częścią badań i analiz w planowaniu strategicznym jest prognoza odnosząca się do oszacowania skali potrzeb społecznych w okresie, na który zaplanowano wdrażanie strategii. Następnym etapem jest wnikliwa analiza strategiczna, która ma na celu określenie 
wniosków wynikających z części diagnostycznej strategii. Wypracowane w tej części konkluzje mają decydujący wpływ na określenie celów strategicznych oraz kierunków rozwoju w dalszych etapach opracowania strategii. W praktyce najczęściej stosowanym narzędziem analizy strategicznej jest analiza zaadaptowana do potrzeb zarządzania publicznego, wspomniana powyżej analiza SWOT.

\section{Rozwój badań społecznych w lokalnej polityce społecznej a zmiany struktury organizacyjnej ośrodków pomocy społecznej oraz znaczenie zawodu specjalisty polityki społecznej}

Choć decyzje strategiczne charakteryzuje, jak uważa Ackoff (1974: 51-52; Miżejewska, 2016) podejście odgórne (top down), to sam dobór środków do ich realizacji i średniookresowe cele opiera się na podejściu oddolnym (bottom up). Oznacza to zazwyczaj, że osoba zarządzająca organizacją bierze odpowiedzialność za ostateczny kształt strategii, ale przekazuje wykonanie precyzyjnej analizy i przygotowanie złożonego planu specjalnie wyodrębnionej komórce do spraw strategii, co wynika z założenia, że planiści mają lepszą umiejętność analizy bieżącej sytuacji i przewidywania przyszłych zmian w otoczeniu. Założenie to jest adaptowane do specyfiki zarządzania w instytucjach publicznych, co wpływa na przeobrażenia związane z organizacją i zarządzaniem w pomocy społecznej.

Na podstawie omówionego w części wstępnej badania struktur organizacyjnych pomocy społecznej (gminnych/miejskich ośrodków pomocy społecznej, miejskich ośrodków pomocy rodzinie) można zauważyć, że zadania dotyczące prowadzenia badań i analiz z zakresu polityki społecznej, głównie z obszaru pomocy społecznej (przedstawiane przede wszystkim w strategiach i programach społecznych oraz w ocenie zasobów w pomocy społecznej), realizowane są najczęściej w następujących komórkach organizacyjnych:

- w sekcji/dziale sprawozdawczości i informacji - jako zasadnicza część zadań tej komórki,

- w zespole/sekcji/dziale strategii, które powstały w celu realizacji badań nad problemami z obszaru pomocy społecznej lub polityki społecznej oraz koordynacją prac nad strategią i programami społecznymi,

- w ramach samodzielnego stanowiska ds. strategii (lub analiz),

- jako zadanie do realizacji dla dyrektora lub jego zastępcy,

- w sekcji/dziale pomocy środowiskowej lub świadczeń społecznych - jako jedno $\mathrm{z}$ wielu zadań tych działów. 
W niektórych miastach (szczególnie wojewódzkich) zadania diagnozowania problemów społecznych, zarządzania strategicznego i standaryzowania w pomocy społecznej realizowane są w urzędach miejskich, zazwyczaj w wydziałach polityki społecznej (co potwierdzają analizy regulaminów organizacyjnych urzędów miejskich, np. w Warszawie i Gdańsku).

W strukturach jednostek organizacyjnych pomocy społecznej, w których wyodrębniono specjalne komórki do spraw badań i strategii (sekcje strategii i informacji lub analiz) zauważa się szerokie spektrum zadań z zakresu diagnozowania oraz innych elementów zarządzania (głównie planowania) strategicznego. Można je podzielić na kilka kategorii, co przedstawiono w tabeli 1 .

Tabela 1. Zadania komórek organizacyjnych pomocy społecznej związane z badaniami problemów społecznych

\begin{tabular}{|c|c|c|}
\hline $\begin{array}{l}\text { Zadania związane z realizacją } \\
\text { i raportowaniem badań }\end{array}$ & $\begin{array}{l}\text { Zadania edukacyjne } \\
\text { i popularyzujące badania }\end{array}$ & $\begin{array}{c}\text { Zadania związane z wykorzystaniem } \\
\text { badań w praktyce }\end{array}$ \\
\hline $\begin{array}{l}\text { - } \text { prowadzenie badań i analiz } \\
\text { w obrębie problematyki społecznej } \\
\text { - gromadzenie możliwie szerokiej } \\
\text { bazy danych i rozeznanie } \\
\text { istniejących materiałów } \\
\text { obrazujących dotychczas } \\
\text { podejmowane działania oraz } \\
\text { problematykę społeczną } \\
\text { - określanie obszarów, które wydają } \\
\text { się być istotne dla przyszłego } \\
\text { planowania działań oraz dla } \\
\text { pełnego oglądu problemów } \\
\text { społecznych } \\
\text { - sporządzanie raportów i informacji } \\
\text { okresowych z podejmowanych } \\
\text { przez ośrodek działań } \\
\text { - przygotowywanie oceny zasobów } \\
\text { w pomocy społecznej } \\
\text { - okresowe raportowanie } \\
\text { na podstawie zgromadzonych } \\
\text { statystyk i badań adresowanych } \\
\text { do pracowników ośrodka }\end{array}$ & $\begin{array}{l}\text { - systemowe przekazywanie } \\
\text { zdobytej w wyniku badań oraz } \\
\text { działań pilotażowych wiedzy } \\
\text { i umiejętności } \\
\text { - koordynowanie zadań } \\
\text { związanych z procesem } \\
\text { szkoleniowym w ośrodku } \\
\text { - reprezentowanie ośrodka } \\
\text { w zakresie uczestnictwa } \\
\text { w różnego rodzaju grupach } \\
\text { roboczych (lokalnych, } \\
\text { regionalnych) oraz w zakresie } \\
\text { merytorycznego udziału } \\
\text { w konferencjach }\end{array}$ & $\begin{array}{l}\text { - } \text { rozwijanie współpracy } \\
\text { z przedstawicielami społeczności } \\
\text { lokalnych, instytucjami } \\
\text { i organizacjami krajowymi } \\
\text { i zagranicznymi zaangażowanymi } \\
\text { w rozwiązywanie konkretnych } \\
\text { problemów społecznych } \\
\text { - uczestniczenie w działaniach } \\
\text { o charakterze programowym, } \\
\text { nawiązywanie współpracy } \\
\text { z partnerami społecznymi } \\
\text { - pozyskiwanie dofinansowania } \\
\text { inicjatyw projektowych oraz } \\
\text { wspieranie w tym zakresie } \\
\text { pracowników jednostek } \\
\text { organizacyjnych } \\
\text { - sporządzanie dokumentów } \\
\text { o charakterze strategicznym } \\
\text { i programowym w obszarze pomocy } \\
\text { społecznej } \\
\text { - planowanie działań z wykorzystaniem } \\
\text { modelu pracy projektowej } \\
\text { - koordynowanie i przeprowadzanie } \\
\text { innowacyjnych działań }\end{array}$ \\
\hline
\end{tabular}

Źródło: opracowanie własne.

Z kolei wśród zadań realizowanych przez osoby pracujące na tzw. samodzielnym stanowisku do spraw strategii, programów i analiz znajdują się obowiązki, które wykonują one w porozumieniu z kierownikami poszczególnych komórek organizacyjnych. Są to: sporządzanie oceny zasobów pomocy społecznej, analiz niezbędnych do przygotowywania lokalnych programów pomocy w zakresie zadań realizowanych 
na podstawie ustawy o pomocy społecznej, analiz możliwości pozyskiwania środków spoza budżetu miasta na realizację zadań pomocy społecznej, a także przygotowywanie projektów dokumentów o charakterze strategicznym opisanych ustawą o pomocy społecznej.

Jak wspomniano, w niektórych miastach zadania z zakresu zarządzania strategicznego w pomocy społecznej realizowane są w urzędach miejskich (głównie w wydziałach polityki społecznej oraz wydziałach rozwoju społecznego). Wówczas wśród zadań przewidzianych dla tych komórek organizacyjnych wymienia się zarówno tworzenie i realizację strategii oraz programów społecznych - ich opracowywanie i monitorowanie, ocenę efektywności pomocy społecznej, diagnozowanie potrzeb w zakresie pomocy społecznej, opracowywanie analiz w tym zakresie, współpracę z komórkami urzędu miejskiego, jak i koordynację oraz zlecanie zadań podmiotom niepublicznym, a także opracowywanie standardów usług społecznych (Warszawa). Do zadań tych włącza się również opracowywanie oceny zasobów w pomocy społecznej oraz konsultacje z ekspertami i specjalistami zewnętrznymi, a także współpracę ze środowiskiem międzynarodowym.

Niewątpliwie przedstawiony zakres zadań związanych z zarządzaniem strategicznym, a szczególnie z diagnozowaniem problemów społecznych i badaniami ewaluacyjnymi, wymaga profesjonalnego przygotowania metodologicznego i merytorycznego w zakresie analizowania, oceniania i projektowania polityki społecznej w różnych jej działach i dziedzinach, co przywołuje refleksje dotyczące znaczenia zawodu polityka społecznego - określanego w klasyfikacji zawodów jako specjalista polityki społecznej (Rozporządzenie Ministra Pracy i Polityki Społecznej z dnia 7 sierpnia 2014 r., Dz.U. 2014, poz. 1145).

Zawód ten wydaje się odpowiadać wyzwaniom, jakie wiążą się z nowymi, wspomnianymi wyżej paradygmatami polityki społecznej, wpływającymi na przeobrażenia struktur i zadania pomocy społecznej. Jest zawodem wymagającym wysokiego poziomu wiedzy, umiejętności i doświadczenia w zakresie różnych nauk, szczególnie społecznych i humanistycznych. Głównym zadaniem specjalisty polityki społecznej jest wdrażanie do praktyki koncepcji i teorii naukowych, powiększanie dotychczasowego stanu wiedzy poprzez badania. Według opisu towarzyszącego klasyfikacji zawodów celem jego wykonywania jest nie tylko tworzenie podstaw teoretycznych polityki społecznej, wskazywanie jej celów, kierunków i instrumentów, ale też badanie i analiza warunków życia społeczeństwa. $Z$ tych celów wynikają różne rodzaje zadań zawodowych, które wykonują tego rodzaju specjaliści - zarówno teoretycznych, jak i praktycznych. Wśród nich można wymienić rozwijanie teorii i metod badawczych, prowadzenie badań, ocenianie i interpretowanie ich wyników, jak i wyciąganie z nich wniosków dla polityki społecznej. Do tych zadań zaliczono również prowadzenie 
działalności eksperckiej, dydaktycznej i popularyzatorskiej (Rozporządzenie Ministra Pracy i Polityki Społecznej z dnia 28 grudnia 2017 r., Dz. U. 2017, poz. 227). Jest to więc zawód, który wiąże się z tworzeniem, przekazywaniem i praktycznym zastosowaniem wiedzy naukowej, zatem jego znaczenie w kontekście obecnych wyzwań stojących przed samorządowymi instytucjami pomocy społecznej i szerzej polityki społecznej, takich jak gromadzenie i analiza specjalistycznej wiedzy na temat diagnozowania i rozwiązywania problemów społecznych, powinno być coraz większe (Wortal Publicznych Służb Zatrudnienia, 2021).

Wyzwania współczesnej polityki społecznej związane m.in. z koncepcją aktywizacji, deinstytucjonalizacji, wielosektorowości czy innowacyjności, rewitalizacji miast, a przede wszystkim zarządzania publicznego sprawiają, że w jednostkach pomocy społecznej zauważalna jest coraz wyraźniej potrzeba prowadzenia rozmaitych badań problemów społecznych. Ma to znaczący związek z planowaniem strategicznym, którego koncepcja wiąże się z tzw. perspektywą planistyczną pochodzącą z zarządzania instytucjami rynkowymi. Wywarła ona znaczący wpływ na potrzebę diagnozowania, bowiem w jej perspektywie do badania tego, co dzieje się w organizacji i jej otoczeniu, proponowała sformalizowany proces tworzenia strategii, oparty na bogatej analizie przypisanej wybranym do tworzenia planów komórkom organizacyjnym. Strategia jest długookresowym planem przedstawionym jako pewien schemat składający się z misji, celów, analizy otoczenia zewnętrznego i wewnętrznego, wariantów strategicznych, wyboru strategii, jej wdrożenia, a następnie kontroli. Metody i techniki zarządzania wypracowane na gruncie instytucji komercyjnych adaptowane są stale do potrzeb instytucji publicznych, również do sektora pomocy społecznej, a najczęściej stosowanymi narzędziami w tym zakresie stały się strategie rozwoju gmin i powiatów oraz strategie rozwiązywania lokalnych problemów społecznych.

Wspomniane założenia bez wątpienia wymagają od osób zaangażowanych w proces planowania strategicznego specjalistycznego przygotowania, dotyczącego organizowania i prowadzenia badań społecznych. Diagnoza powinna być bowiem złożonym badaniem ilościowo-jakościowym i ukazywać aktualny stanu rozwoju gminy lub powiatu, wskazywać występujące tendencje oraz związki przyczynowo-skutkowe i współzależności rozwojowe, a także zawierać prognozę rozwojową w określonej perspektywie czasowej i przestrzenne porównanie skali problemów społecznych. Powinna też obrazować uwarunkowania zbadanych problemów, np. demograficzne czy gospodarcze.

Przygotowanie tak złożonego planu poleca się coraz częściej specjalnie wyodrębnionej komórce do spraw strategii, w której pracują osoby mające umiejętność 
analizy bieżącej sytuacji i przewidywania przyszłych zmian w otoczeniu. Założenie to, również pochodzące z zarządzania instytucjami komercyjnymi, jest adaptowane do specyfiki zarządzania w instytucjach publicznych, co wpływa na przeobrażenia związane z organizacją i zarządzaniem w pomocy społecznej. Potrzeba prowadzenia analiz problemów i kwestii społecznych w lokalnej polityce społecznej implikuje zarówno zmiany struktur (schematów) organizacyjnych pomocy społecznej, jak i zaangażowanie w proces planowania strategicznego specjalistów posługujących się instrumentarium potrzebnym do realizacji rozmaitych badań, służących różnym etapom diagnozowania.

W związku z przedstawionymi obserwacjami wydaje się, że zawodem coraz bardziej potrzebnym w instytucjach pomocy społecznej, także w centrach usług społecznych, będzie specjalista polityki społecznej. Osoby przygotowane do tej profesji mogą wdrażać koncepcje i teorie naukowe, a przez prowadzenie badań lokalnych problemów społecznych powiększać dotychczasowy stan wiedzy. Mogą wskazywać też cele lokalnej polityki społecznej, jej kierunki i instrumenty oraz badać i analizować warunki życia społeczeństwa.

\section{Bibliografia}

Ackoff, R.L. (1974). Redesigning the future: A systems approach to societal problems. New York, NY: John Wiley \& Sons.

Ansoff, H.I. (1985). Zarzadzanie strategiczne. Warszawa: PWE.

Baran, G. (2020). Social Innovation Living Labs as Platforms to Co-design Social Innovations. Journal of Intercultural Management, 12(1); 36-57. DOI: 10.2478/joim-2019-0031.

Brodowicz, D.P., Stelmach-Fita, B. (2017). Baza wiedzy o regionie i jej rola w rozwoju terytorialnym. Biuletyn KPZK PAN, 268: 186-209.

Czekaj, K. (2007). Socjologia Szkoły Chicagowskiej i jej recepcja w Polsce. Katowice: GWSH.

Czekaj, K., Niesporek, A., Zawartka-Czekaj, M. (2009). Ruda Śląska. Od problemów społecznych górnośląskiego miasta do polityki miejskiej. Katowice: GWSH.

Czekaj, K., Zawartka, M. (2015). Problemy społeczne, mapy badawcze, planowanie społeczne - perspektywa smart city. Studia Ekonomiczne. Zeszyty Naukowe Uniwersytetu Ekonomicznego w Katowicach, 243: 35-49.

Danecki, J. (1998). Uwagi o kwestiach społecznych. W: Kwestie społeczne na przełomie stuleci (23-34), G. Firlit-Fesnak (red.). Warszawa: Elipsa.

Drobiazgiewicz, J. (2019). The importance of a participatory budget in sustainable city management. Zeszyty Naukowe Akademii Morskiej w Szczecinie, 59(131): 146-153.

Frieske, K.W. (1990) Socjologia w działaniu. Nadzieje i rozczarowania. Warszawa: Wydawnictwo Uniwersytetu Warszawskiego. 
Frieske K.W. (2008) Nauki społeczne w służbie spraw publicznych - polskie tradycje. W: Środowisko i warsztat ewaluacji (13-29), A. Haber, M. Szałaj (red). Warszawa: Polska Agencja Rozwoju Przedsiębiorczości.

Głąbicka, K. (2013). Strategie rozwiązywania problemów społecznych jako przykład realizacji lokalnej polityki społecznej. Wrocławskie Studia Politologiczne, 15: 182-193.

Górniak, J., Mazur, S. (2012). Analiza polityk publicznych i programowania w obszarze strategii rozwoju. W: Zarządzanie strategiczne rozwojem (185-220), J. Górniak, S. Mazur (red.). Warszawa: Ministerstwo Rozwoju Regionalnego.

Grewiński, M., Karwacki, A. (2009). Strategia - istota, reguły i wyzwania implementacji ze środowiska biznesu do polityki społecznej. W: Strategie $w$ polityce społecznej (11-40), M. Grewiński, A. Karwacki (red.). Warszawa: Mazowieckie Centrum Polityki Społecznej.

Grewiński, M., Lizut, J. (2013). Pomoc społeczna jako realizator efektywnych usług socjalnych. Toruń: Regionalny Ośrodek Polityki Społecznej.

Grochowski, M. (2011). Regionalne obserwatoria terytorialne jako instrument monitorowania rozwoju regionów: warsztaty w Białobrzegach, 20-21 maja 2011 roku. Mazowsze Studia Regionalne, 7: 241-246.

Klimek, M. (2020). Strategia rozwiązywania problemów społecznych jako narzędzie zarządzania rozwojem systemu pomocy społecznej w powiecie. Aspekty teoretyczne i metodologiczne. Praca Socjalna 4(35): 51-67. DOI: 10.5604/01.3001.0014.3618.

Klimowicz, M. (2015). Żywe Laboratoria jako innowacyjne narzędzie zarządzania miastami. W: (Re) organizacja w zarzadzaniu miastami w Polsce w kontekście wyzwań rozwojowych (186-19), A. Wiktorska-Święcka (red.). Wrocław: Oficyna Wydawnicza ATUT.

Klingemann, J.I. (2013). Iluzja polityki społecznej opartej na dowodach naukowych. Przykład zjawiska uzależnienia od alkoholu. Normy, Dewiacje i Kontrola Społeczna, 14: 139-155.

Kożuch, B. (2004). Zarzadzanie publiczne $w$ teorii i praktyce polskich organizacji. Warszawa: Wydawnictwo Placet.

Kożuch, B. (2016). Współczesne perspektywy rozwiązywania problemów zarządzania publicznego. Zarzadzanie i Finanse Journal of Management and Finance, 14(2): 167-178.

Krzyszkowski, J., Przywojska, J. (2009). Lokalne strategie rozwiązywania problemów społecznych jako instrument decentralizacji polityki społecznej. W: Strategie w polityce społecznej (221-238), M. Grewiński, A. Karwacki (red.). Warszawa: Mazowieckie Centrum Polityki Społecznej.

Kubin, J. (1998). Diagnoza społeczna. W: Encyklopedia socjologii, t. 1. (134-135), Z. Bokszański, A. Kojder (red.). Warszawa: Oficyna Naukowa.

Leminen, S. (2013). Coordination and Participation in Living LabNetworks. Technology Innovation Management Review, 3(11): 5134-135. 14.

Miżejewska, E. (2016). Szkoła planistyczna w zarządzaniu strategicznym i jej krytycy. W: Zarzadzanie, organizacje i organizowanie - przeglad perspektyw teoretycznych (124-138), K. Klincewicz (red.). Warszawa: Elipsa. DOI: 10.7172/978-83-65402-29-5.2016.wwz.9.

Mintzberg, H. (1991). Learning 1, planning O. Reply to Igor Ansoff. Strategic Management. Journal, 12(6): 463-466. 
Mintzberg, H. (1994). The rise and fall of strategic planning. Essex: Prentice Hall.

Mitton, C., Adair, C.E., McKenzie E., Patten, S.B., Waye Perry, B. (2007). Knowledge Transfer and Exchange: Review and Synthesis of the Literature. The Milbank Quarterly, 85(4): 729-768.

Obłój, K. (1998). Strategia organizacji: w poszukiwaniu trwałej przewagi konkurencyjnej. Warszawa: PWE.

Olejniczak, K. (2008). Mechanizmy wykorzystania ewaluacji. Warszawa: Scholar.

Petelewicz, M., Drabowicz, T. (2016). Jakość życia - globalnie i lokalnie Pomiar i wizualizacja. Łódź: Wydawnictwo Uniwersytetu Łódzkiego.

Piasny, J. (1993), Poziom i jakość życia ludności oraz źródła i mierniki ich określania. Ruch Prawniczy, Ekonomiczny i Socjologiczny, 55(2): 73-92.

Podkońska, A. (2016). Ewaluacja w lokalnej polityce społecznej przykład projektów aktywnej integracji. Problemy Polityki Społecznej. Studia i Dyskusje, 35(4): 129-146.

Raczkowski, K. (2015). Zarządzanie publiczne. Teoria i praktyka. Warszawa: Wydawnictwo Naukowe PWN.

Rozporządzenie Ministra Pracy i Polityki Społecznej z dnia 28 grudnia 2017 r. w sprawie klasyfikacji zawodów i specjalności na potrzeby rynku pracy oraz zakresu jej stosowania (Dz. U. 2017, poz. 227).

Rybka, I., Trawkowska, D. (2009). Wytyczne do tworzenia samorządowej strategii rozwiązywania problemów społecznych. W: Strategie w polityce społecznej (239-269), M. Grewiński, A. Karwacki (red.). Warszawa: Mazowieckie Centrum Polityki Społecznej.

Supernat, J. (2004). Administracja publiczna w świetle koncepcji New Public Governance, https:// www. supernat.pl/artykuly (dostęp: 29.02.2021).

Surdej, A., Fitz-Gibbon, C.T., Picciotto. R. (2013). Ewaluacja w polityce publicznej. Warszawa: Difin.

Szatur-Jaworska, B. (2013), Diagnoza i diagnozowanie w polityce społecznej. W: Polityka społeczna (109-126), G. Firlit-Fesnak, M. Szylko-Skoczny (red.). Warszawa: Wydawnictwo Naukowe PWN.

Sześciło, D., Medins. A., Niziołek, M, Jakubek-Lalik, J. (2014). Administracja i zarządzanie publiczne. Nauka o współczesnej administracji. Warszawa: Stowarzyszenie Absolwentów Wydziału Prawa i Administracji Uniwersytetu Warszawskiego Poligraf.

Sztumski, J. (2020). Wstęp do metod i technik badań społecznych. Katowice: Śląsk.

Theiss, M. (2010). Historyczne źródła i czynniki rozwoju ewaluacji. W: Ewaluacja w służbach społecznych (15-23), B. Szatur-Jaworska (red.). Warszawa: Mazowieckie Centrum Polityki Społecznej.

Tokarski J. (red.) (1980). Słownik wyrazów obcych. Warszawa: PWN.

Ustawa z dnia 12 marca 2004 r. o pomocy społecznej (Dz. U. 2004 nr 64, poz. 593).

Ustawa z dnia 19 lipca 2019 r. o realizowaniu usług społecznych przez centrum usług społecznych (Dz.U. 2019, poz. 1818).

Wortal Publicznych Służb Zatrudnienia (2021). Wyszukiwarka opisów zawodów - Specjalista polityki społecznej, https://psz. praca.gov.pl/rynek-pracy/bazy-danych/klasyfikacja-zawodow-i-specjalnosci/wyszukiwarka-opisow-zawodow//-/klasyfikacja_zawodow/ 
zawod/263305?_jobclassificationportlet_WAR_nnkportlet_backUrl=https\%3A\%2F\%2Fpsz. praca.gov.pl\%2Frynek-pracy\%2Fbazy-danych\%2Fklasyfikacja-zawodow-i-specjalnosci\%2Fwyszukiwarka-opisow-zawodow\%2F\%2F-\%2Fklasyfikacja_zawodow\%2Flitera\%2FS (dostęp: 12.06.2021).

Woźniak, J. (2012). Dylematy modelu instytucjonalnego zarządzania rozwojem województwa. Studia KPZK PAN, CXL: 167-184.

Wyszomirski, O. (2017). Zrównoważony rozwój transportu w miastach a jakość życia. Transport Miejski i Regionalny, 12: 27-32.

Ziółkowski, J. (1972). Socjologia i planowanie społeczne. Warszawa: PWN. 